\title{
PECULIARITIES OF FORMATION AND REPORT SUBMISSION BY FARMS
}

\author{
Natalia Koval ${ }^{1}$
}

\begin{abstract}
The article reveals the role, significance, features of the formation and submission of reports by farms. Attention is drawn to the fact that at the present stage the problems of transformation of the domestic agricultural sector are intensifying. Farming is considered one of the most common forms of entrepreneurial activity in the agricultural sector. In an uncertain, ever-changing environment, the effective functioning of an enterprise often depends on the ability to develop and implement creative management decisions based on analytical information. In order for all farm reporting to be as useful as possible, it should be simpler in structure and order of filling and at the same time - concise. The composition and reporting structure of farms depends on the one hand on the types of accounting, and on the other - on the information needs of users. In addition, the organizational and legal form of the entity and the form of accounting should be considered. If the farm is established in the form of a legal entity, it is subject to the requirements of mandatory accounting. The peculiarities of the organization of farm accounting and reporting are determined. It is noted that in addition to the volume of activity, other factors also influence, among which it is worth noting the specialization, the number of business transactions, the system of taxation of the farm. The specifics of financial and statistical reporting of farms as legal entities and natural persons-entrepreneurs are revealed. A farm as a legal entity compiles the same reports as a regular agricultural enterprise. A farm (natural person-entrepreneur) prepares reports as an ordinary natural person-entrepreneur. Peculiarities of formation and submission of tax reporting are investigated. If the farm is on the general system of taxation, it is obliged to file a declaration of income tax (the form approved by the order of the Ministry of Finance dated 20.10.2015 № 897 as amended). Taxpayers who are registered during the reporting (tax) year (newly created) pay income tax on the basis of an annual tax return for the period of activity in the reporting (tax) year. If the farm is on a simplified taxation system, it will submit, depending on the selected group, either a declaration of a single taxpayer of the third group (legal entity), or a declaration of a single taxpayer of the fourth group (form of declaration approved by order of the Ministry of Finance from 19.06.2015 № 578 with changes). It is established that farms that own or rent wells and are required to report in accordance with IFRS. Such reporting is subject to publication together with the auditor's report on its website (in full). The impact of qualitative characteristics of reporting and the principles of its formation on the completeness of economic processes and features of economic activity in the reporting system.
\end{abstract}

Key words: farming, organization of accounting, taxation, reporting, factors of influence.

JEL Classification: M21, M41, H25

\section{Introduction}

The development of the agricultural sector has led to the emergence of various organizational and legal forms of entrepreneurship in agriculture - from individual entrepreneurs and ending with farms, private enterprises, societies, associations and more. Farming is considered one of the most common forms of entrepreneurial activity in the agricultural sector.

For most agricultural regions of the country, farms are one of the main activities and an important

Corresponding author:

${ }^{1}$ Vinnytsia National Agrarian University, Ukraine

E-mail: natkov@i.ua

ORCID: https://orcid.org/0000-0002-2877-4302

ResearcherID: L-5920-2018 element of the agricultural production system. In general, farming can be in the form of a legal entity or in the form of individual entrepreneurs. Each form of farming has its advantages and disadvantages. Reporting of business entities is the final step of the accounting system, which summarizes and systematizes information about the activities of the economy, necessary for all stakeholders to make effective economic decisions. The composition and structure of reporting depends on the one hand on the types of accounting, and on the other - on the information

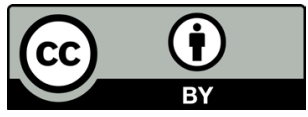

This is an Open Access article, distributed under the terms of the Creative Commons Attribution CC BY 4.0 
needs of users. In addition, it is necessary to take into account the organizational and legal form, size and scope of the farm.

Disclosure of information about the activities of the farm is through the publication of financial statements. According to the Law of Ukraine "On Accounting and Financial Reporting in Ukraine", the financial statements of enterprises are not a trade secret of the enterprise.

In an uncertain, ever-changing environment, the effective functioning of an enterprise often depends on the ability to develop and implement creative management decisions based on analytical information. The problem of the ratio of the amount of reported data and the quality of information, its usefulness and demand comes to the fore. In order for all farm reporting to be as useful as possible, it should be simpler in structure and order of filling and at the same time - concise (Gudzenko, 2018).

The study of the specifics of the organization of accounting, information support of the process of financial support, taxation and the formation of various types of reporting of agricultural enterprises, including farms, is given considerable attention in the works of domestic and foreign scientists: M.I. Bondar, N.M. Gudzenko (2018), V.M. Zhuk, G.M. Kaletnik (2020), N.I. Koval, O.A. Podolyanchuk (2019), N.L. Pravdyuk (2010), M.M. Shigun and others. However, most of the above scientists study the vast majority of the nature, classification, structure and opportunities for improvement of individual reporting forms, focusing more on the financial statements of agricultural enterprises, including farms.

However, it is important to further study the existing approaches and features of the formation and submission of all types of reporting by farms.

\section{Organizational and legal form of the business entity}

The composition and reporting structure of farms depends on the one hand on the types of accounting, and on the other - on the information needs of users. In addition, the organizational and legal form of the entity and the form of accounting should be considered.

If the farm is established in the form of a legal entity, it is subject to the requirements of mandatory accounting. Requirements on the obligation to keep records and reporting by enterprises are provided by: the Commercial Code of Ukraine (Articles 19, 71, 90, 145) (Commercial Code of Ukraine, 2003); Laws of Ukraine "On Accounting and Financial Reporting in Ukraine" of 16.07.99 № 996-X (1999), "On Business Associations" of 25.06.1991 № 1251-XII with changes and additions (1991), "About the state statistics" from 19.09.1992 № 2614-XII with changes and additions (1992), "About the state support of small business" from 19.10.2000 (2063-III (item 11) with changes and additions ), "On the farm" from 20.12.1991 № 2009 (Article 24) with changes and additions (1991); "On Amendments to the Tax Code of Ukraine and Certain Other Legislative Acts of Ukraine Concerning the Simplified System of Taxation, Accounting and Reporting" № 4618-VI of March 22, 2012, as amended (2012); National Accounting Standards.

Farms without the status of a legal entity established on the basis of the activities of natural personsentrepreneurs are not required to keep accounts.

According to part one of Art. 2 of the Law "On Accounting", this Law applies to all legal entities established in accordance with the laws of Ukraine, regardless of their organizational and legal forms and forms of ownership, as well as representative offices of foreign economic entities that are required to keep accounts and submit financial statements in accordance with the law (Podolyanchuk, Koval, Gudzenko, 2019; Law on Accounting, 1999].

Thus, if a farm is a legal entity, it must keep accounts in the general order established for legal entities. The same is established by Art. 28 of the Law "On Farming": such a farm keeps accounts of the results of its activities and submits to the relevant authorities financial statements, statistical information and other data provided by law (Podolyanchuk, Koval, Gudzenko, 2019; Law on Farming, 2003).

However, today the farm can be created in the form of both legal entities and individuals. According to the amendments to the Law "On Amendments to the Law of Ukraine" On Farming "to stimulate the establishment and operation of family farms" № 1067-VIII of 31.03.2016, a farm without the status of a legal entity is organized on the basis of the activities of an individual - entrepreneur and has the status of a family farm, subject to the use of labor of members of such a farm, which are exclusively a natural person-entrepreneur and members of his family in accordance with Article 3 of the Family Code of Ukraine (Podolyanchuk, Koval, Gudzenko, 2019).

Therefore, accounting is not required for individual farmers.

Based on the conditions of management, farms differ in the area of land under cultivation: from a few hectares of arable land (small in size) to hundreds and thousands of hectares (medium and large).

As of July 1, 2021, 48.4 thousand farms were registered in Ukraine. In 2013, a record number of farmers was registered - 49.1 thousand. However, by 2015 their number decreased by $11 \%$, ie by 5467 . From 2015 to 2021 there is only a positive growth trend, almost $11 \%$ or 4714 farms (Agropolit, 2021).

Farms can cultivate both their own land and leased land. Therefore, it is obvious and appropriate to divide farms into the following types: private, private- 
leased and leased, which will affect the organization of accounting and further reflection of transactions in the reporting.

Farms have different areas of specialization, but most of them are engaged in growing cereals and oilseeds.

The total area of agricultural land of farms is 4.439 million hectares, then under cereals were 2.2 million hectares, oil - 1.5 million hectares. Farmers are also engaged in the cultivation of sugar beets, potatoes, vegetables, food melons, but their share in the structure of crops does not exceed 1\% (Podolyanchuk, Koval, Gudzenko, 2019).

The size of the farm, its specialization affect the organization of accounting, formation and content of reporting information. Therefore, clarification of the criteria for determining the scope of activities of the farm is necessary in order to establish approaches to the possibility of simplifying accounting in them.

At the same time, the criteria established by the Commercial Code of Ukraine for determining the subjects of micro-entrepreneurship (the number of employees does not exceed 10 people and the annual income is 2 million euros) do not take into account the national characteristics of management. After all, even 10 employees can cultivate a large area of land and perform a large amount of work, and the annual income of 2 million euros is typical for medium and large enterprises (Podolyanchuk, Koval, Gudzenko, 2019).

Based on the selected criteria at the stage of organization of accounting and in order to optimize the structure of reporting information, it is advisable to classify farms according to the criteria proposed by the Law of Ukraine "On Accounting and Financial Reporting". However, the value criteria set out in the Law № 996 regarding the book value of assets and the amount of income received in relation to farms should be reduced and appropriate changes made to the Guidelines for the organization and maintenance of farms № 189 and Guidelines for the use of accounting registers for small enterprises № 422 (Koval, Gudzenko, 2019; Methodical recommendations, 2009).

\section{Factors influencing the formation of reporting}

Solving the problem of inconsistency in the classification of farms in economic and accounting legislation will provide a differentiated approach to the organization of the accounting process.

The organization of accounting and reporting of the farm, in addition to the volume of activity, is influenced by other factors, including specialization, the number of business transactions, the taxation system and so on. The list of factors that must be taken into account in the process of organizing accounting and reporting of the farm is presented in Figure 1.

Among the features that affect the accounting and reflection of transactions in the reporting, there are the following:

1. In farms, operations that are not typical for other forms of entrepreneurial activity are quite common. This applies to the formation of farm capital, the distribution of its income, labor relations of farm members (the classifier of professions provides specific names of professions for farm members) and the payment of remuneration for work (farm members are not paid. They receive part of income), which is determined as a result of the activity of the farm, and the requirements for the minimum amount are set only for wages received under the employment contract (Article 95 of the Labor Code), formation of reporting (Code of Labor Laws of Ukraine, 1971).

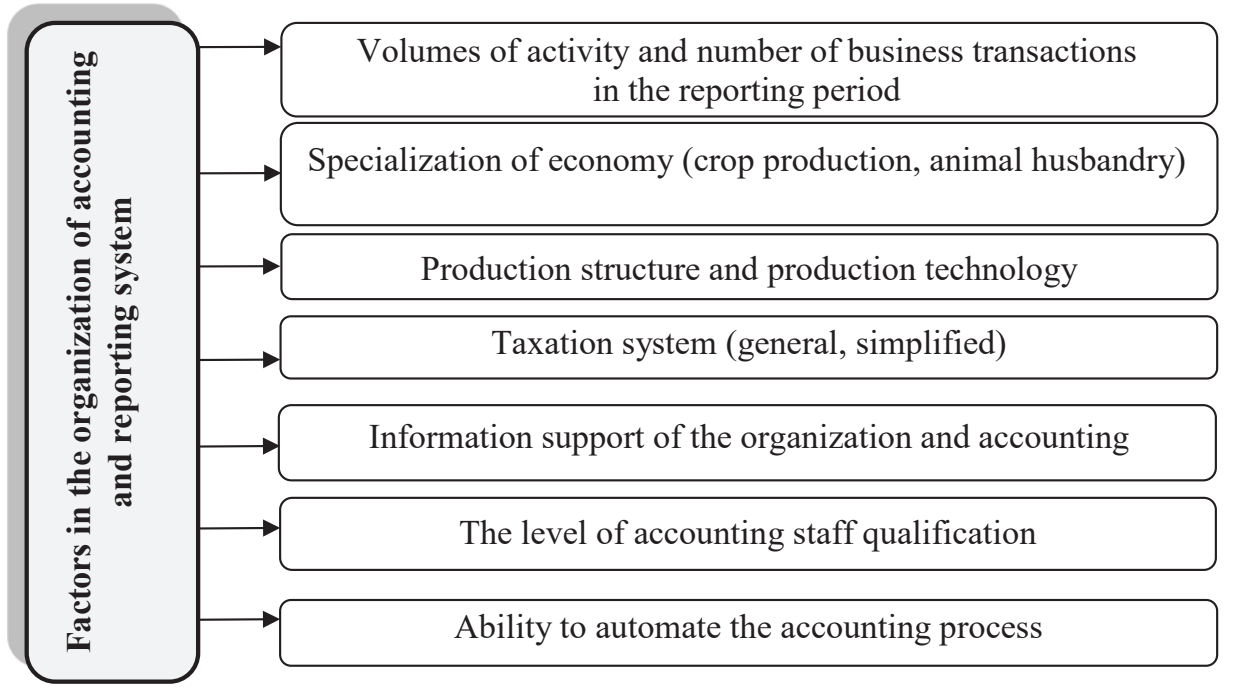

Figure 1. Factors in the organization of accounting and reporting system of the farm Source: (Podolyanchuk, Koval, Gudzenko, 2019) 


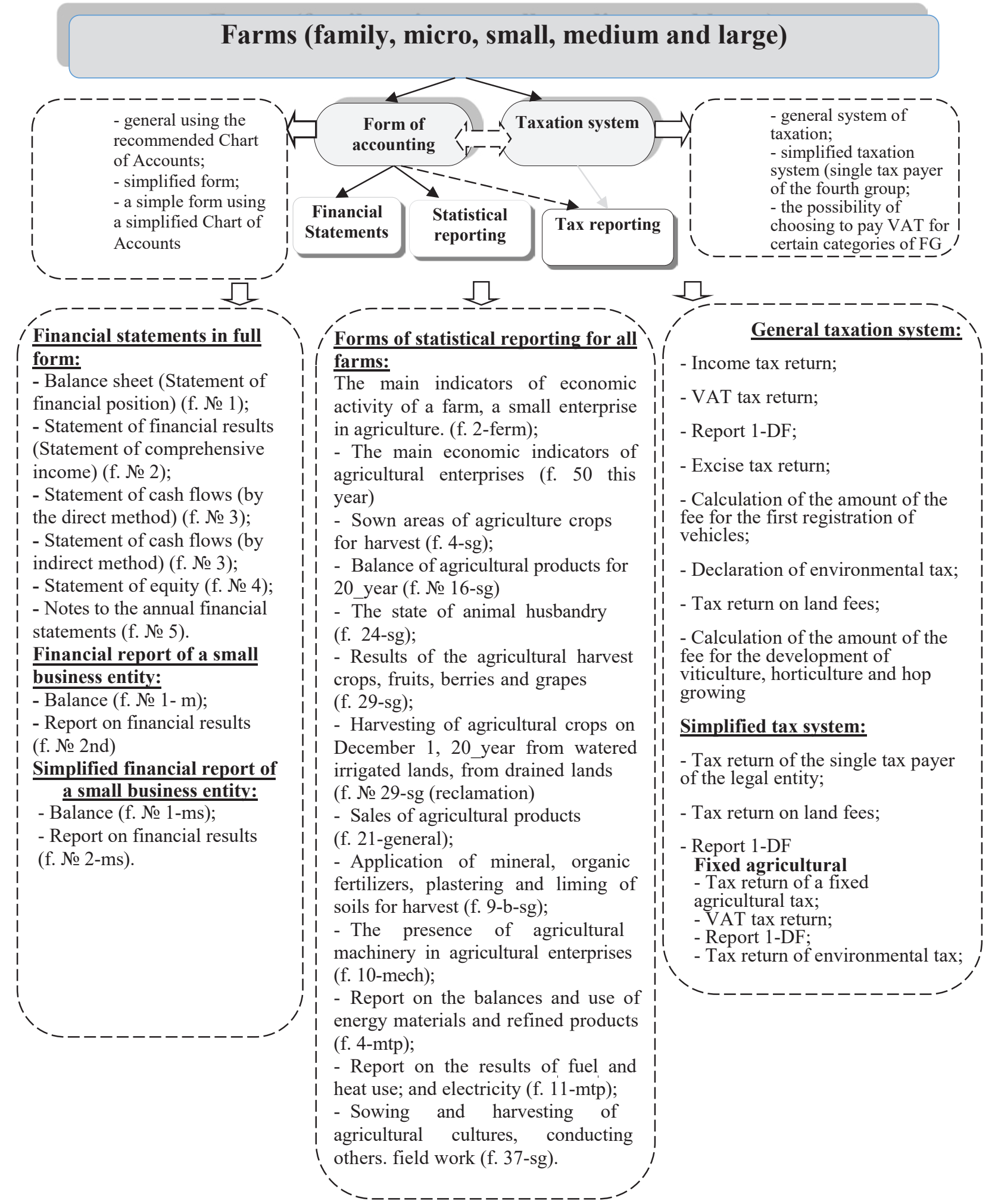

Figure 2. The impact of the size and activity of farms on accounting and reporting

Source: (Podolyanchuk, Koval, Gudzenko, 2019)

2. Farms are engaged in the cultivation of agricultural products and specialize mainly in crop production, which requires proper assessment, accounting and reporting of land and operations related to their use and lease. A significant number of farms specialize in horticulture and berry growing, which requires the reflection of operations with long-term biological assets. 
3. Quite often in small farms there is a problem of qualification of accountants, because accounting and reporting is carried out directly by the head of the farm or members of his or her family. This feature affects the quality of accounting and reporting information. Therefore, it is proposed to simplify the accounting process as much as possible or to involve consulting firms specializing in the provision of accounting services in the formation of reporting.

4. There is a need to reflect in the accounting and reporting of state support to farms, provided on a revolving basis.

5. It is possible to choose a simplified system of taxation for certain groups of farms, which affects the choice of form of accounting and reporting (Podolyanchuk, Koval, Gudzenko, 2019).

Disclosure of information about the activities of the farm is through the publication of financial statements. According to the Law of Ukraine "On Accounting and Financial Reporting in Ukraine", the financial statements of enterprises are not a trade secret of the enterprise (Figure 2).

\section{The main types of reporting of the farm}

Farms prepare financial, statistical and tax reports.

1. Financial statements are financial statements that contain information about the financial condition, results of activities for the reporting period.

The possibility of using a simple form of accounting and reporting by small businesses is provided by the Law "On state support of small business" from 19.10.2000 № 2063. Article 11 of this Law states that the simplified form of accounting, as well as the simplified taxation system, can be used along with the generally accepted form of accounting at the choice of the small business entity, ie it is allowed, not mandatory (Law on State Support of Small Business, 2000).

Enterprises, which according to the results of activity for the last year are determined in accordance with the current legislation by small business entities, apply the National Regulation (Standard) of Accounting 25 "Simplified Financial Statements" in the current (reporting) year. If such enterprises, as well as newly created as a result of activities for the 1st quarter or 1 half of the current (reporting) year can not be recognized as small businesses in accordance with applicable law, the financial statements of these enterprises are prepared for this and subsequent periods of the current (reporting) year. in accordance with the provisions (standards) of accounting, approved by the order of the Ministry of Finance of Ukraine on March 31, 1999 № 87, which was registered in the Ministry of Justice of Ukraine on June 21, 1999 for № 391/3684. Enterprises that according to the results of activity for 9 months of the current (reporting) year cannot be recognized as subjects of small business according to the current legislation, can make the financial report for 9 months and the reporting year with application of the Provision (standard) 25 (Podolyanchuk, Koval, Gudzenko, 2019; NP (S) BU Simplified Financial Reporting, 2000).

The vast majority of farms are small businesses and in accordance with applicable law form Simplified Financial Statements.

According to the Resolution of the Cabinet of Ministers of Ukraine of July 11, 2018 № 547 for enterprises, which in accordance with the Law of Ukraine "On Accounting and Financial Reporting in Ukraine" establishes abbreviated financial statements in the Balance Sheet (Statement of Financial Position) and Statement of financial results (Statement of comprehensive income) (other than those required to prepare financial statements in accordance with International Financial Reporting Standards), and companies that keep simplified accounting of income and expenses in accordance with tax legislation, submit to the appropriate authorities annual financial statements for small businesses. The selected category includes farms that are considered small and micro enterprises.

Large and medium-sized farms have the right to choose the IFRS reporting format. For micro- and small FG IFRS-reporting format is not appropriate, because it requires additional costs for its formation and accounting support of the process of generalization of reporting data. However, in accordance with the changes introduced by the Law of Ukraine dated 05.10.2017 № 2164-VIII, which came into force on 01.01.2018 for those farms that have a well on their own balance (or the farmer rents it and produces water and is considered the primary water user), there is a need to prepare financial statements in accordance with international standards (IFRS). Volumes of extracted water and directions of its use do not matter (Podolyanchuk, Koval, Gudzenko, 2019).

That is, if the farm by volume of activity refers to small businesses and even has the right to choose a simple or simplified form of accounting in the presence of a well or on condition of its lease (especially relevant for farms engaged in horticulture), must form IFRS reporting. Changes updated Part 2 of Art. 12-1 of the Law on Accounting, which states the need to prepare financial statements in accordance with international standards, including enterprises engaged in mining activities of national importance: "Enterprises that in accordance with the law prepare financial statements and consolidated financial statements in international standards that are required to ensure accounting in accordance with accounting policies in accordance with international standards after the submission of the first financial statements or consolidated financial statements in accordance with international standards, which is recognized as such 
in the manner prescribed by international standards. Thus, starting from 2019, accounting should be conducted in accordance with accounting policies according to international standards, regardless of the direction and volume (Podolyanchuk, Koval, Gudzenko, 2019).

2. Statistical reporting is a report compiled by all economic entities (including farms) and which provides information to the state statistics bodies on the assessment of the state and development of the state economy and the planning of macroeconomic indicators.

Each farm submits to the state statistics bodies of Ukraine several types of different forms of reporting that characterize its activities, as a comprehensive reflection of the results of farm activities is summarized through statistical observations. However, the Law of Ukraine "On State Statistics" states: "Primary data obtained by state statistics bodies from respondents during statistical observations are confidential information protected by law and used exclusively for statistical purposes in a consolidated impersonal form." That is, primary statistics are used for consolidated statistical work, compilation of collections, surveys of the socio-economic situation and research (Law on State Statistics, 1992).

In addition to the above forms of statistical reporting, farms may compile other reports that reflect other aspects of their economic activities.

Tax reporting is a document (declaration, calculation), which according to the TCU is submitted by taxpayers to the State Tax Service and on the basis of which the tax is charged and/or paid, collected (mandatory payment) (Podolyanchuk, Koval, Gudzenko, 2019).

Taxpayers are recognized, including legal entities and their separate subdivisions, which have, receive (transfer) objects of taxation or carry out activities (operations) that are subject to taxation in accordance with the TCU or tax laws, and which are obliged to language for the payment of taxes and fees. In Ukraine, national and local taxes and fees are set. National taxes and fees established by Art. 9 of the TCU, and the list of local taxes is provided in Art. 10 TCU (Tax Code of Ukraine, 2010).

Depending on the chosen system of taxation - general or simplified, you need to submit the appropriate declarations.

1. If a legal entity is in the general system of taxation, it is obliged to file a declaration of income tax (the form approved by the order of the Ministry of Finance dated 20.10.2015 № 897 as amended). Taxpayers who are registered during the reporting $(\operatorname{tax})$ year (newly created) pay income tax on the basis of an annual tax return for the period of activity in the reporting $(\operatorname{tax})$ year. If a legal entity switches to a simplified taxation system, depending on the selected group, either the declaration of the single taxpayer of the third group (legal entity) or the declaration of the single taxpayer of the fourth group will be submitted. Both forms of such a declaration were approved by the order of the Ministry of Finance dated 19.06.2015 № 578 as amended in 2021.

If the farm is newly established, therefore, taking into account paragraphs. 291.4.7 TCU, the first reporting period it will be on the general system of taxation.

2. If the newly established farm considers it appropriate to voluntarily register as a VAT payer, there is an obligation to file a VAT return (form approved by the order of the Ministry of Finance from 28.01.2016 № 21 as amended by the order of the Ministry of Finance from 01.06.2018). The reporting (tax) period is equal to a calendar month.

3. According to paragraph 240.1 of the TCU, the payers of the environmental tax are economic entities that emit pollutants into the atmosphere by stationary sources of pollution or directly into water bodies. Stationary source of pollution in accordance with paragraphs. 14.1.230 A TCU is an enterprise, shop, unit, installation or other fixed object that retains its spatial coordinates for a certain period of time and releases pollutants into the atmosphere and/or discharges of pollutants into water bodies. The basic tax (reporting) period is equal to a calendar quarter (the form approved by the order of the Ministry of Finance dated August 17, 2015 № 715). If the farm has such sources of pollution that are listed in paragraphs. 14.1.230 TCU, it automatically passes into the category of environmental tax payers (Tax Code of Ukraine, 2010).

4. If a farm uses the work of individuals on the terms of an employment agreement (contract) or on other terms provided by law, the following may be submitted to the SBGS:

- Report on the amounts of accrued SSC (form № D4 - monthly, approved by the order of the Ministry of Finance dated 11.04.2016 № 441 with changes dated 15.05.2018 Order № 511);

- Tax calculation of the amounts of income accrued (paid) in favor of individuals and the amounts of tax withheld from them (form №1 SF - quarterly, approved by the order of the Ministry of Finance dated 13.01.2015 № 4).

Thus, users of farm accounting information have the right to be all members of society, despite the fact that their economic interests differ significantly. Satisfaction of users' interests occurs through financial reporting, which goes through the stages of formation, submission and disclosure.

\section{Conclusions}

Given the information requests of users and the requirements for submission of financial statements 
by farms as self-employed legal entities, it should be noted that the farm with the creation of a legal entity (Article 1 of the Law of Ukraine "On Farming") is subject to the Law of Ukraine "On Accounting and financial statements in Ukraine", Procedure № 419 and relevant UAS (Podolyanchuk, Koval, Gudzenko, 2019).

In accordance with the law, the farm keeps accounts of the results of its work and submits to the relevant authorities financial statements, statistical information and other data established by the legislation of Ukraine, which allows to determine the financial result, make calculations with the budget and prepare reports. Accounting can be done independently (by the accounting department of the farm, one person - the farmer or a member of his family), or with the involvement of consulting or auditing companies.
There is nothing significant about farm reporting. As an exception, there are farms that own or rent well and are required to report in accordance with IFRS. Such statements shall be published together with the auditor's report on its website (in full). That is, the business will be required to have its own website where you can publish financial statements. So, if there is no page - you need to create. Second, the financial statements must be confirmed by the auditor's report. Third, the annual financial statements will be made public on the same page.

For the average small farm, which has a well and will not switch to IFRS, there is no obvious responsibility, as such farms are payers of the single tax of the 4th group and do not pay income tax.

\section{References:}

Pravdiuk, N. L. (Eds.) (2010). Aktualni pytannia orhanizatsii oblikovo-analitychnoho protsesu na pidpryiemstvakh ahropromyslovoho kompleksu Ukrainy [Current issues of organization of accounting and analytical process at the enterprises of the agro-industrial complex of Ukraine]. Vinnytsia: PP Baliuk.

Hospodars'kyy kodeks Ukrayiny [Economic Code of Ukraine] (2003). Ofitsiinyi sait Verkhovnoyi Rady Ukrayiny [Official web site of the Verkhovna Rada of Ukraine]. Available at: https://zakon.rada.gov.ua/laws/show/43615\#Text (accessed September 15, 2021).

Gudzenko, N. M., Koval, N. I., \& Plakhtiy, T. F. (2018). Vplyv informatsiynykh potreb korystuvachiv na strukturu ta popovnennya finansovoyi zvitnosti [The impact of user information needs on the structure and replenishment of financial statements]. Economics, finance, management: current issues of science and practice, 5(33), pp. $102-113$.

Kaletnik, H. M., \& Koziar, N. O. (2020). Stratehichni pidkhody do investuvannia ahrarnoho sektoru Ukrainy $\mathrm{v}$ suchasnykh umovakh rozvytku APK [Strategic approaches to investing in the agricultural sector of Ukraine in modern conditions of agro-industrial complex development]. Ekonomika APK - Economics of agro-industrial complex, 12(314), 81-89.

Kodeks zakoniv pro pratsyu Ukrayiny: zakon Ukrayiny [Labor Code of Ukraine: Law of Ukraine] (1971). Ofitsiinyi sait Verkhovnoyi Rady Ukrayiny [Official web site of the Verkhovna Rada of Ukraine]. Available at: https://zakon.rada.gov.ua/laws/show/322-08 (accessed 20 September 2021).

Metodychni rekomendatsiyi shchodo zastosuvannya rehistriv zhurnal'no-ordernoyi formy obliku dlya sil's'kohospodars'kykh pidpryyemstv: nakaz Minahropolityky Ukrayiny [Methodical recommendations on the use of registers of journal-order form of accounting for agricultural enterprises: the order of the Ministry of Agrarian Policy of Ukraine] (2009). Ofitsiinyi sait Verkhovnoyi Rady Ukrayiny [Official web site of the Verkhovna Rada of Ukraine]. Available at: https://zakon.rada.gov.ua/laws/show/v0390555-09 (accessed 20 September 2021).

Ofitsiynyy sayt Agropolit [Official web site of the Mistry of Agropolitics of Ukraine]. Available at: https://agropolit.com/ spetsproekty/897-programa-rozvitku-fermerstva-ukrayini-dotatsiyi-programa-pidtrimki-molodogo-fermerazakon-pro-lokalne-virobnitstvo/ (accessed 25 September 2021).

Podatkovyy kodeks Ukrayiny: Zakon Ukrayiny [Tax Code of Ukraine: Law of Ukraine] (2010). Ofitsiinyi sait Verkhovnoyi Rady Ukrayiny [Official web site of the Verkhovna Rada of Ukraine]. Available at: https://zakon.rada.gov.ua/laws/show/2755-17\#Text (accessed September 25, 2021).

Podolyanchuk, O. A., Koval, N. I., \& Gudzenko, N. M. (2019). Oblik v fermerskykh hospodarstvakh: navchalnyy posibnyk. [Accounting in farms: a textbook]. Kyiv: «Tsentr uchbovoyi literatury». (in Ukrainian)

Pro bukhhalterskyy oblik ta finansovu zvitnist v Ukrayini: Zakon Ukrayiny [On Accounting and Financial Reporting in Ukraine: Law of Ukraine] Ofitsiinyi sait Verkhovnoyi Rady Ukrayiny [Official web site of the Verkhovna Rada of Ukraine]. Available at: https://zakon.rada.gov.ua/laws/show/996-14\#Text (accessed September 25, 2021).

Pro hospodarski tovarystva: Zakon Ukrayiny [On Business Associations: Law of Ukraine] (1991). Ofitsiinyi sait Verkhovnoyi Rady Ukrayiny [Official web site of the Verkhovna Rada of Ukraine]. Available at: https://zakon.rada.gov.ua/laws/show/1576-12 (accessed 25 September 2021).

Pro derzhavnu pidtrymku maloho pidpryyemnytstva: Zakon Ukrayiny [On state support of small business: Law of Ukraine]. (2000). Ofitsiinyi sait Verkhovnoyi Rady Ukrayiny [Official web site of the Verkhovna Rada of Ukraine]. Available at: http://zakon2.rada.gov.ua/laws/show/2063-14 (accessed 25 September 2021).

Pro derzhavnu statystyku: Zakon Ukrayiny [On state statistics: Law of Ukraine On state statistics: Law of Ukraine]. (1992). Ofitsiinyi sait Verkhovnoyi Rady Ukrayiny [Official web site of the Verkhovna Rada of Ukraine]. Available at: http://zakon2.rada.gov.ua (accessed 25 September 2021). 
Vol. 2 No. 3, 2021

Pro zatverdzhennya Natsionalnoho polozhennya (standartu) bukhhalterskoho obliku 25 «Sproshchena finansova zvitnist»: Nakaz Ministerstva finansiv Ukrayiny [On approval of the National Regulation (standard) of accounting 25 "Simplified financial statements": Order of the Ministry of Finance of Ukraine] (2000). Ofitsiinyi sait Verkhovnoyi Rady Ukrayiny [Official web site of the Verkhovna Rada of Ukraine]. Available at: https://zakon.rada.gov.ua/laws/show (accessed 24 September 2021).

Zakon Ukrayiny [On farming: Law of Ukraine]. (2003). Ofitsiinyi sait Verkhovnoyi Rady Ukrayiny [Official web site of the Verkhovna Rada of Ukraine]. Available at: http://zakon.nau.ua/doc/?uid=1088.283.2 (accessed 25 September 2021). 